Biol. Stud. 2020: 14(1); 33-40 • DOI: https://doi.org/10.30970/sbi.1401.611

www.http://publications.Inu.edu.ua/journals/index.php/biology

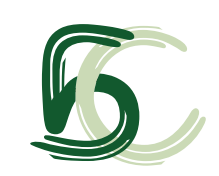

UDC: 615.25:612.616.2

\title{
CHARACTERISTICS OF $\mathrm{Ca}^{2+}, \mathrm{Mg}^{2+}$-DEPENDENT ATP HYDROLYSIS IN SPERM CELLS OF INFERTILE MEN
}

\author{
O. I. Meskalo®*, R. V. Fafula®, Z. D. Vorobets \\ Danylo Halytsky Lviv National Medical University, 69, Pekarska St., Lviv 79010, Ukraine \\ *Corresponding author: e-mail: gradst_meskalo_olga@meduniv.Iviv.ua; \\ kaf_medicalbiology@meduniv.Iviv.ua
}

Meskalo O.I., Fafula R.V., Vorobets Z.D. Characteristics of $\mathrm{Ca}^{2+}, \mathrm{Mg}^{2+}$-dependent ATP hydrolysis in sperm cells of infertile men. Studia Biologica, 2020: 14(1); 33-40 • DOI: https://doi.org/10.30970/ sbi.1401.611

Disturbances of fertilizing potential of spermatozoa are closely associated with dysfunction of ion-transporting ATPases, in particular $\mathrm{Ca}^{2+}, \mathrm{Mg}^{2+}$-ATPase. Reduced activity of tapsigargin-resistant and tapsigargin-sensitive $\mathrm{Ca}^{2+}, \mathrm{Mg}^{2+}$-ATPase leads to disruption of $\mathrm{Ca}^{2+}$-homeostasis and is characteristic for abnormal spermatozoa (pathoospermia). In order to study the peculiarities of action of $\mathrm{Ca}^{2+}, \mathrm{Mg}^{2+}$-ATPase, we determined the initial reaction rate, the maximum (plateau) amount of the reaction product and the characteristic reaction time. To determine these kinetic parameters of $\mathrm{Ca}^{2+}, \mathrm{Mg}^{2+}$-dependent hydrolysis of ATP catalyzed by $\mathrm{Ca}^{2+}, \mathrm{Mg}^{2+}$-ATPase, the dynamics of product accumulation of the ATP-hydrolases reaction was studied. The obtained curves were linearized in the coordinates $\{P / t ; P\}$. Analyzing the changes in the activity of $\mathrm{Ca}^{2+}, \mathrm{Mg}^{2+}$-ATPase, the kinetics of primary-active transport of calcium ions through the plasma membrane and membranes of intracellular $\mathrm{Ca}^{2+}$-stores in saponin-permeabilized spermatozoa of infertile men was studied. It was shown that in normozoospermic samples, the transport of $\mathrm{Ca}^{2+}$ ions through the plasma membrane is characterized by a higher capacity than through the membranes of intracellular $\mathrm{Ca}^{2+}$-stores, but it occurs with practically the same initial velocity and characteristic reaction time. It was found that in pathospermic samples, transport of $\mathrm{Ca}^{2+}$ ions with the participation of both components of $\mathrm{Ca}^{2+}, \mathrm{Mg}^{2+}$ ATPase occurs less intensively and is characterized by a lower capacity compared to spermatozoa of men with preserved fertility. Specific changes in the kinetic parameters of $\mathrm{Ca}^{2+}, \mathrm{Mg}^{2+}$-dependent hydrolysis of ATP lead to inhibition of tapsigargin-resistant and tapsigargin-sensitive $\mathrm{Ca}^{2+}, \mathrm{Mg}^{2+}$-ATPase activity and cause a decrease in fertilizing potential of spermatozoa.

(C) 2020 O.I. Meskalo et al.; Published by the Ivan Franko National University of Lviv on behalf of Біологічні Студії / Studia Biologica. This is an Open Access article distributed under the terms of the Creative Commons Attribution License (http://www.budapestopenaccessinitiative.org and Creative Commons Attribution 4.0 License), which permits unrestricted reuse, distribution, and reproduction in any medium, provided the original work is properly cited.

ISSN 1996-4536 (print) •ISSN 2311-0783 (on-line) • Біологічні Студії / Studia Biologica • 2020 • Том 14/№1 • C. 33-40 
Keywords: $\mathrm{Ca}^{2+}, \mathrm{Mg}^{2+}$-ATPase, ATP hydrolysis, spermatozoa, male infertility, pathospermia

\section{INTRODUCTION}

Infertility is one of the most important medical and biological problem. According to statistics $15 \%$, of married couples face this problem during the reproductive period. Nowadays, large-scale studies are being conducted all over the world to investigate the causes of impaired reproductive function and to develop methods that restore fertility [1]. Approximately $50 \%$ of the infertility cases are related to male factor which has a tendency to increase. Defective functions of spermatozoa is the main cause of male infertility $[11,13]$. The most common abnormal parameters are low motility (asthenozoospermia), low sperm count (oligozoospermia), or a combination of these abnormalities (oligoasthenozoospermia) [9, 14].

Calcium ions play a pivotal role in sperm physiology, specifically in sperm hyperactivation, chemotaxis and motility which depend on intracellular free calcium concentration [7]. For the normal functioning of sperm cells, it is necessary to change rapidly the intracellular concentration of calcium ions in response to certain stimuli. $\mathrm{Ca}^{2+}, \mathrm{Mg}^{2+}-\mathrm{AT}-$ Pase (EC 3.6.1.38) plays a pivotal role in $\mathrm{Ca}^{2+}$ extrusion from cytoplasm maintaining its concentration in low nanomolar range (10-100 nM). Total activity of $\mathrm{Ca}^{2+}, \mathrm{Mg}^{2+}$-ATPase consists of thapsigargin-resistant plasmatic membrane and thapsigargin-sensitive ATPase of internal $\mathrm{Ca}^{2+}$-stores. Our previous results showed that asthenozoo-, oligoasthenozoo- and leucocytospermic patients have significantly impaired thapsigarginresistant and thapsigargin-sensitive $\mathrm{Ca}^{2+}, \mathrm{Mg}^{2+}$-ATPase activity compared to healthy men [12]. Lowered activity of $\mathrm{Ca}^{2+}, \mathrm{Mg}^{2+}$-ATPase activity is likely to contribute to the disruption of $\mathrm{Ca}^{2+}$ homeostasis, a hallmark of abnormal sperm cells [4].

The aim of present study was to study the properties of membrane-bound $\mathrm{Ca}^{2+}$ transport systems in spermatozoa of fertile (normozoospermia) and infertility men (oligozoospermia and asthenozoospermia).

\section{MATERIALS AND METHODS}

Reagents. The following reagents were used in the present study: ATP, ouabain, thapsigargin, EGTA (Sigma, USA), saponin (from Quillaja Saponaria Molina pract.; Acros organics, Belgium). Other reagents of the domestic production were of reagent grade or laboratory grade.

Donors and semen sample preparation. Human semen was obtained from 7 healthy volunteers and 12 infertile men with asthenozoospermia (AS) and oligoasthenozoospermia (OLAS) undergoing routine semen analysis for couple infertility at Lviv Regional Clinical Hospital (Ukraine). Control group consisted of healthy men with somatic fertility, normozoospermia $(\mathrm{N})$ and confirmed parenthood (married for 3-10 years and having 1-3 healthy children).

Approval for study was taken from the Ethics Committe of Danylo Halytsky Lviv National Medical University (Ethical Committee Approval, protocol No 6 from March 29, 2017). Terms of sample selection meet the requirements of the principles of Convention of Europe Council on human rights, Helsinki Declaration on protection of human rights and biomedicine and the laws of Ukraine. All patients and healthy donors were matched by age and gave written informed consent to participate in research. Exclusion criteria:

ISSN 1996-4536 (print) • ISSN 2311-0783 (on-line) • Біологічні Студії / Studia Biologica • 2020 • Том 14/№1 • С. 33-40 
subjects who are currently on any medication or antioxidant supplementation were not included. In addition, subjects with infertility over 10 years, azoospermia, testicular varicocele, genital infection, chronic illness and serious systemic diseases, smokers and alcoholic men were excluded from the study because of their well-known high seminal reactive oxygen species levels and decreased antioxidant activity which may affect calcium level. Samples were obtained by the masturbation after 3-4 days of sexual abstinence and processed immediately upon liquefaction. The classical semen parameters of spermatozoa concentration, motility, and morphology were examined according to World Health Organization criteria (2010) [19].

Cell preparation. Biochemical studies were carried out in the Department of Medical Biology of Danylo Halytsky Lviv National Medical University. Sperm cells were washed from semen plasma by 3 times centrifugation at 3,000 $\times \mathrm{g}$ for $10 \mathrm{~min}$ in media which contained $(\mathrm{mM})$ : $120 \mathrm{NaCl}, 30 \mathrm{KCl}, 30$ Hepes $(\mathrm{pH} 7.4)$. Protein concentration in the samples was determined by Lowry method using a kit to determine its concentration ("Simko Ltd"). Determination of ATPases activities was carried out in the permeabilized spermatozoa. The detergent saponin in a final concentration of $0.5 \%$ was added to sperm suspension for permeabilization of sperm membranes. Saponin interacts with membrane cholesterol, selectively removing it and leaving holes in the membrane [6].

Enzymatic studies. $\mathrm{Ca}^{2+}, \mathrm{Mg}^{2+}$-ATPase activity was assayed using the following incubation medium (mM): $150 \mathrm{KCl}, 5 \mathrm{MgCl}_{2}, 5$ ATP, $0.05 \mathrm{CaCl}_{2}, 1$ ouabain, $1 \mathrm{NaN}_{3}$, 20 Hepes-Tris ( $\mathrm{pH} \mathrm{7.4;} \mathrm{at} 37^{\circ} \mathrm{C}$ ). $\mathrm{Ca}^{2+}, \mathrm{Mg}^{2+}$-ATPase activity was calculated as the difference between ATPase activity in $\mathrm{Ca}^{2+}$-containing media and $\mathrm{Ca}^{2+}$-free medium (1 mM EGTA). The reaction was started by addition of aliquot of permeabilized sperm cells. After a $5 \mathrm{~min}$ incubation, $1 \mathrm{ml}$ of a stop solution containing $1.5 \mathrm{M}$ sodium acetate, $3.7 \%$

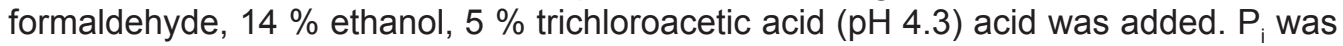
determined by the Fiske-Subbarow method using assay kit "Simko Ltd" (Ukraine) [18]. Specific inhibitor of internal $\mathrm{Ca}^{2+}$-stores, thapsigargin $(0.01 \mu \mathrm{M})$, was used to evaluate thapsigargin-sensitive ATPase.

Kinetic calculations. Studies of $\mathrm{Ca}^{2+}, \mathrm{Mg}^{2+}$-ATP-dependent hydrolysis of sperm ATP were performed in a standard incubation medium, that was modified by the time of incubation. The apparent kinetic parameters of $\mathrm{Ca}^{2+}, \mathrm{Mg}^{2+}$-dependent ATP hydrolysis are the initial reaction rate $V_{0}$, the maximum (plate) amount of the reaction product $P_{\max }$ and the characteristic reaction time was determined by linearization at $\{P / t ; P\}$, where $P$ is the amount of reaction product $\left(\mathrm{P}_{\mathrm{i}}\right)$ and $t$ is the incubation time [8].

Statistics analysis. Data are expressed as means \pm standard error of the numbers of determinations. Differences between paired sets of data were analysed using paired Student's t-tests in Microsoft Excel. Differences were considered significant at $p<0.05$ as the minimum significance level.

\section{RESULTS AND DISCUSSION}

For determination of the kinetic parameters of $\mathrm{Ca}^{2+}, \mathrm{Mg}^{2+}$-dependent ATP hydrolysis in saponin-permeabilized spermatozoa, the dynamics of inorganic phosphate $\left(P_{i}\right)$ accumulation in ATP-hydrolysis reaction wad studies. To do that sperm cells of fertile and infertile men were incubated in incubation medium during different time intervals (1-10 min). The experimental data showed that the curves of $\mathrm{Ca}^{2+}, \mathrm{Mg}^{2+}$-dependent hydrolysis of ATP in sperm cells tend to saturate (Fig. 1). 


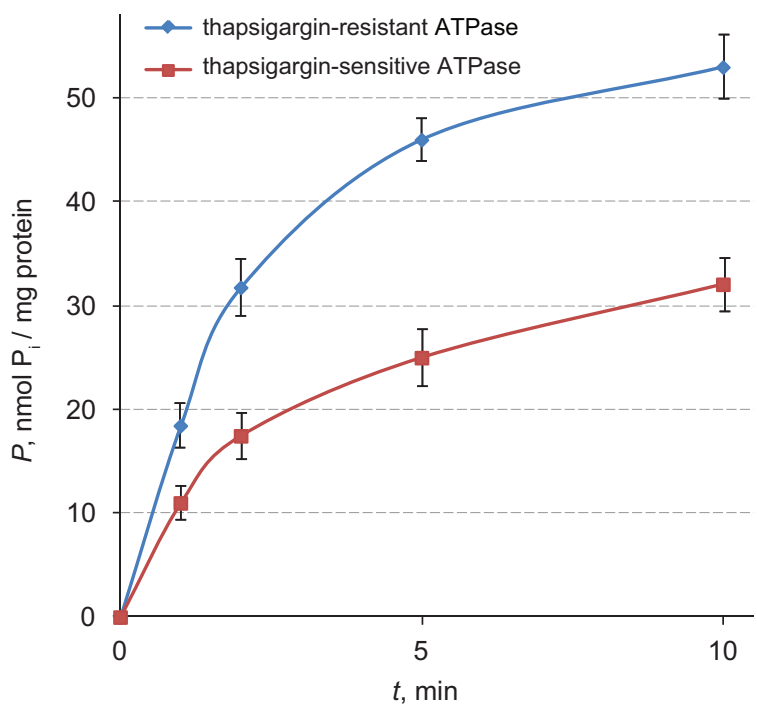

Fig. 1. Dynamics of accumulation of inorganic phosphate in $\mathrm{Ca}^{2+}, \mathrm{Mg}^{2}$-dependent hydrolysis of ATP in normozoospermic samples, $M \pm m, n=7$

Рис. 1. Динаміка накопичення неорганічного фосффату в процесі $\mathrm{Ca}^{2+}, \mathrm{Mg}^{2}-$ залежного гідролізу АТФ у сперматозоїдах нормозооспермічних чоловіків, $\mathrm{M} \pm \mathrm{m}, \mathrm{n}=7$

The analysis of the obtained results shows that accumulation of $\mathrm{P}_{\mathrm{i}}$ in reaction catalyzed by thapsigargin-resistant ATPase in the normozoospermic samples in time interval 0-2 min correspond to zero order reactions. In this time interval, the graph of dependence of the amount of $\mathrm{P}_{\mathrm{i}}$ on incubation time is almost linear. Similar dependence is observed for thapsigargin-sensitive ATPase.

By linearization of the obtained data in the coordinates $\{P / t ; P\}$ (Fig. 2), the apparent kinetic parameters of the reaction of $\mathrm{Ca}^{2+}, \mathrm{Mg}^{2+}$-dependent hydrolysis of ATP were calculated (see Table).

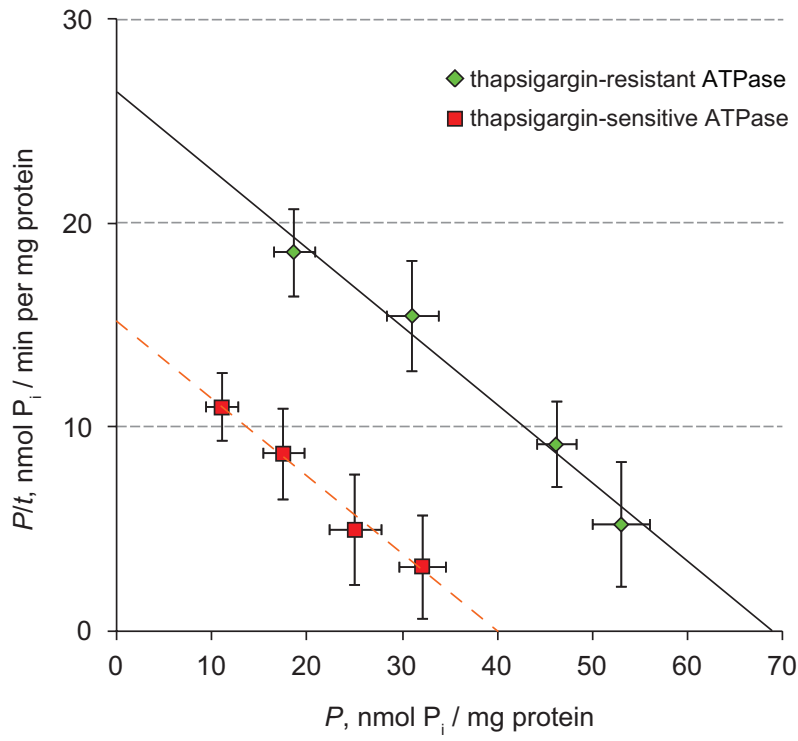

Fig. 2. Linearization of accumulation curves of inorganic phosphate $\mathrm{P}_{i}$ in reaction of $\mathrm{Ca}^{2+}, \mathrm{Mg}^{2+}$-dependent hydrolysis of ATP in normozoospermic samples in coordinates $\{P / t ; P\} ; \mathrm{n}=7$; $r>0.95$

Рис. 2. Лінеаризація кривих накопичення неорганічного фосфрату $\mathrm{P}_{\mathrm{i}}$ у процесі $\mathrm{Ca}^{2+}, \mathrm{Mg}^{2+}$-залежного гідролізу АТФ у сперматозоїдах нормозооспермічних чоловіків у координатах $\{P / t ; P\} ; \mathrm{n}=7 ; \mathrm{r}>0,95$

As can be seen from the Table, the values of the apparent kinetic parameters of ATP hydrolysis catalyzed by thapsigargin-resistant and thapsigargin-sensitive ATPase

ISSN 1996-4536 (print) • ISSN 2311-0783 (on-line) • Біологічні Студії / Studia Biologica • 2020 • Том 14/№1 • C. 33-40 
of the normozoospermic samples differ significantly among themselves. In the absence of a significant difference between values $\tau$ and $V_{0}$ of ATP hydrolysis reaction, the value $P_{\max }$ in reaction catalyzed by thapsigargin-resistant ATPase was 1.75 times greater compared to values for thapsigargin-sensitive ATPase.

\section{Kinetic parameters of $\mathrm{Ca}^{2+}, \mathrm{Mg}^{2+}$-dependent hydrolysis of ATP in sperm cells of normo- zoo- and pathospermic men, $M \pm m, n=5-7$}

Кінетичні параметри $\mathrm{Ca}^{2+}, \mathrm{Mg}^{2+}$-залежного гідролізу АТФ у сперматозоїдах чоловіків із нормозоо- та патоспермією, $\mathrm{M} \pm \mathrm{m}, \mathrm{n}=\mathbf{5 - 7}$

\begin{tabular}{|c|c|c|c|}
\hline \multirow[t]{2}{*}{ Groups } & \multirow[b]{2}{*}{ Normozoospermia } & \multicolumn{2}{|c|}{ Pathospermia } \\
\hline & & asthenozoospermia & $\begin{array}{c}\text { oligoasthenozoo- } \\
\text { spermia }\end{array}$ \\
\hline
\end{tabular}

Thapsigargin-resistant $\mathrm{Ca}^{2+}, \mathrm{Mg}^{2+}$-ATPase

\begin{tabular}{|l|c|cc}
\hline$V_{0}$, nmol $P_{\mathrm{i}} /$ min per mg protein & $26.17 \pm 4.04$ & $7.8 \pm 2.12^{* *}$ & $6.5 \pm 1.72^{* *}$ \\
\hline$P_{\max }$, nmol $\mathrm{P}_{\mathrm{i}} /$ mg protein & $70.5 \pm 6.8$ & $36.6 \pm 6.4^{* *}$ & $33.7 \pm 2.3^{* * *}$ \\
\hline$\tau$, min & $2.77 \pm 0.68$ & $5.02 \pm 1.84$ & $5.51 \pm 1.74$
\end{tabular}

Thapsigargin-sensitive $\mathrm{Ca}^{2+}, \mathrm{Mg}^{2+}$-ATPase
$V_{0}$, nmol $\mathrm{P}_{\mathrm{i}} /$ min per mg protein
$15.22 \pm 2.9$
$8.27 \pm 3.6$
$4.72 \pm 1.9^{*}$
$P_{\max }, \mathrm{nmol} \mathrm{P}_{\mathrm{i}} / \mathrm{mg}$ protein
$40.1 \pm 3.65^{\$}$
$15.95 \pm 1.64^{* * *+}$
$15.6 \pm 2.28^{* * * *}$
$\tau, \min$
$2.7 \pm 0.53$
$2.29 \pm 0.9$
$3.93 \pm 1.3$

Comments: ${ }^{*} \mathrm{P}<0.05 ;{ }^{* *} \mathrm{P}<0.01 ;{ }^{* * *} \mathrm{P}<0.001$ compared to fertile men

${ }^{\$} \mathrm{P}<0.01$ compared to thapsigargin-resistant $\mathrm{Ca}^{2+}, \mathrm{Mg}^{2+}$-ATPase

Примітки: "P<0,05; " $P<0,01 ;$;"* $P<0,001$ стосовно значень у здорових донорів

${ }^{\$} \mathrm{P}<0,01$ стосовно значень для тапсигаргін-резистентної $\mathrm{Ca}^{2+}, \mathrm{Mg}^{2+}$-АТФази

Based on these results, we assume that in sperm cells of fertile men, $\mathrm{Ca}^{2+}$-transport by thapsigargin-resistant ATPase is characterized by a higher capacity compared to $\mathrm{Ca}^{2+}$-transport by thapsigargin-sensitive ATPase. These results are in disagreement with data reported in lymphocytes and cells of the submandibular salivary gland $[3,17]$. It was found that transport of $\mathrm{Ca}^{2+}$ ions by $\mathrm{Ca}^{2+}, \mathrm{Mg}^{2+}$-ATPase of plasmatic membrane in healthy donors is slower and less intensive, but it is characterized by higher capacity in comparison with $\mathrm{Ca}^{2+}, \mathrm{Mg}^{2+}$-ATPase of endoplasmic reticulum. Our results might be explained by structural organization of spermatozoa. Since cytoplasm of spermatozoa has a restricted volume and sperm cells have highly polarized morphology, they pose a unique challenge to maintain $\mathrm{Ca}^{2+}$-homeostasis [15]. Standard components of $\mathrm{Ca}^{2+}$ signaling for somatic cell are present in spermatozoa in a slightly modified form [16]. The primary candidate for the intracellular $\mathrm{Ca}^{2+}$-store in spermatoza is the acrosome, since human sperm do not contain the endoplasmic reticulum [5]. The presence of thapsigargin-sensitive $\mathrm{Ca}^{2+}$-ATPase SERCA 2 mainly localized to the acrosome and mid-piece was demonstrated in mammalian spermatozoa $[2,10]$.

The curves of $\mathrm{Ca}^{2+}, \mathrm{Mg}^{2+}$-dependent hydrolysis of ATP of sperm cells of the infertile men with asthenozoospermia and oligoastenozoospermia have a similar appearance, but differ from the values for the normozoospermic samples (Fig. 3).

ISSN 1996-4536 (print) • ISSN 2311-0783 (on-line) • Біологічні Студії / Studia Biologica • 2020 • Том 14/№1 • C. 33-40 
A

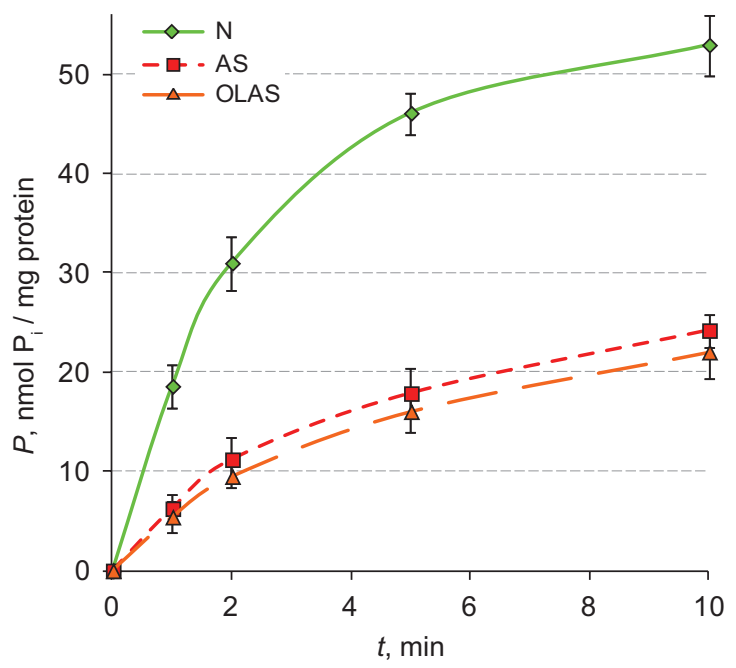

B

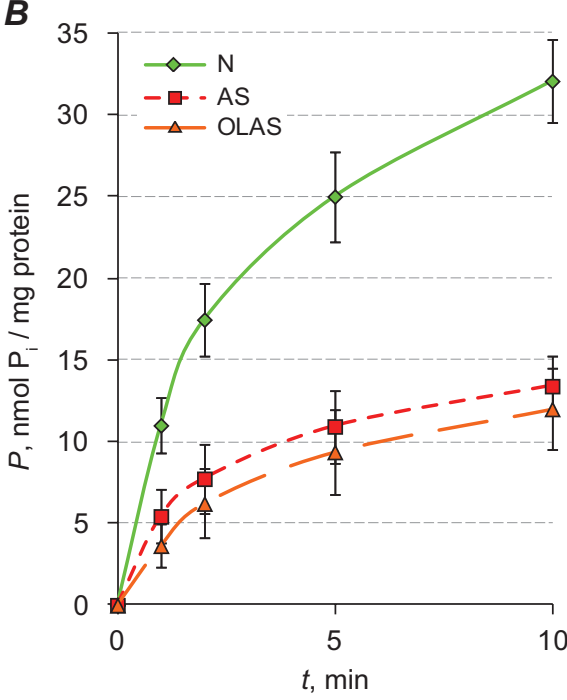

Fig. 3. Dynamics of accumulation of inorganic phosphate in the reaction catalyzed by thapsigargin-resistant $(\boldsymbol{A})$ and thapsigargin-sensitive $(\boldsymbol{B})$ ATPase in normozoo- and pathospermic samples, $\mathrm{M} \pm \mathrm{m}$, $\mathrm{n}=5-7$

Рис. 3. Динаміка накопичення неорганічного фосфату у процесі $\mathrm{Ca}^{2+}, \mathrm{Mg}^{2+}$-залежного гідролізу АТФ за участю тапсигаргін-резистентної $(\boldsymbol{A})$ і тапсигаргін-чутливої $\mathrm{Ca}^{2+}, \mathrm{Mg}^{2+}$-АТФази $(\boldsymbol{B})$ сперматозоїдів чоловіків із нормозоо- та патоспермією, $\mathrm{M} \pm \mathrm{m}, \mathrm{n}=5-7$

As follows from the data in the table, the values of apparent kinetic parameters of $\mathrm{Ca}^{2+}, \mathrm{Mg}^{2+}$-dependent hydrolysis of ATP by thapsigargin-resistant ATPase in sperm cells from the infertile men differ significantly from these values in the normozoospermic samples. Specifically, the value of $V_{0}$ of ATP hydrolysis in astheno- and oligoasthenozoospermic samples is reduced 4 times compared to normozoospermic samples. The value of $P_{\max }$ in pathospermic samples is twice lower in comparison with the normozoospermic samples. The $\tau$ values of reaction catalyzed by thapsigargin-resistant ATPase in spermatozoa from men with astheno- and oligoasthenozoospermia are 1.8-2.0 times greater than values in normozoospermic samples.

In the absence of a significant difference in the value of $\tau$ reaction catalyzed by thapsigargin-sensitive ATPase in normozoo- and pathospermic samples, the value of $V_{0}$ in astheno- and oligoasthenozoospermic samples is reduced 2.0 times compared to normozoospermic samples. The value of $P_{\max }$ in pathospermic samples is 2.5 times higher than normozoospermic samples. Based on these results, we assume that in sperm cells of infertile men, the transport of $\mathrm{Ca}^{2+}$ ions is less active and characterized by a lower capacity than in fertile men.

\section{CONCLUSION}

The analysis of the alterations in hydrolase activity of thapsigargin-resistant and thapsigargin-sensitive $\mathrm{Ca}^{2+}, \mathrm{Mg}^{2+}$-ATPase showed that primary active transport of $\mathrm{Ca}^{2+}$ ions is less intensive and characterized by lower transport capacity in sperm cells of the infertile men in comparison with fertile men. 


\section{COMPLIANCE WITH ETHICAL STANDARDS}

Human Rights: All procedures performed in studies involving human participants were in accordance with the ethical standards of the institutional and/or national research committee and with the 1964 Helsinki declaration and its later amendments or comparable ethical standards.

1. Agarwal A., Mulgund A., Hamada A., Chyatte M.R. A unique view on male infertility around the globe. Reprod. Biol. Endocrinol., 2015; 13: 37.

[DOI: https://doi.org/10.1186/s12958-015-0032-1; Google Scholar]

2. Correia J., Michelangeli F., Publicover S. Regulation and roles of $\mathrm{Ca}^{2+}$ stores in human sperm. Reproduction, 2015; 150(2): 65-76.

[DOI: https://doi.org/10.1530/REP-15-0102; Google Scholar]

3. Fafula R.V., Besedina A.S., lefremova U.P., Vorobets Z.D. Characterization of $\mathrm{Ca}^{2+}, \mathrm{Mg}^{2+}$ dependent hydrolysis of ATP by peripheral blood lymphocytes of patients with rheumatoid arthritis and ankylosing spondylitis. ECPB, 2012; 4: 81-87. (In Ukrainian)

4. Harchegani A., Irandoost A., Mirnamniha M., Rahmani H., Tahmasbpour E., Shahriary A. Possible mechanisms for the effects of calcium deficiency on male infertility. Int. J. Fertil. Steril., 2019; 12(4): 267-272.

[DOI: https://doi.org/10.22074/ijfs.2019.5420; Google Scholar]

5. Herrick S.B., Schweissinger D.L., Kim S.W., Bayan K.R., Mann S., Cardullo R.A. The acrosomal vesicle of mouse sperm is a calcium store. J Cell Physiol, 2005; 202(3): 663-671.

[DOI: https://doi.org/10.1002/jcp.20172; Google Scholar]

6. Jamur M.C., Oliver C. Permeabilization of cell membranes. Methods Mol. Biol., 2010; 588: 63-66.

[DOI: https://doi.org/10.1007/978-1-59745-324-0_9; Google Scholar]

7. Jimenez-Gonzalez C., Michelangeli F., Harper C.V., Barratt C.L., Publicover S.J. Calcium signalling in human spermatozoa: A specialized 'toolkit' of channels, transporters and stores. Hum. Reprod. Update., 2006; 12: 253-267.

[DOI: https://doi.org/10.1093/humupd/dmi050; Google Scholar]

8. Kosterin S.A., Burchynskaya N.F. The method for determining the characteristics kinetics of the $\mathrm{Ca}^{2+}$-transport systems subcells structures of smooth muscles. Ukr Biokhim J, 1987; 59(2): 66-69. (In Russian)

[PMID: 3576725; Google Scholar]

9. Lamb D.J. Semen analysis in 21 st century medicine: the need for sperm function testing. Asian J Androl, 2010; 12: 64-70.

[DOI: https://doi.org/10.1038/aja.2009.4; Google Scholar]

10. Lawson C, Dorval V, Goupil S, Leclerc P. Identification and localisation of SERCA 2 isoforms in mammalian sperm. Mol. Hum. Reprod., 2007; 13(5): 307-316. [DOI: https://doi.org/10.1093/molehr/gam012; Google Scholar]

11. Lee L.K., Foo K.Y. Recent insights on the significance of transcriptomic and metabolomic analysis of male factor infertility. Clin. Biochem., 2014; 47(10-11): 973-82. [DOI: https://doi.org/10.1016/j.clinbiochem.2014.05.053; Google Scholar]

12. Meskalo O.I., Fafula R.V., Lychkovskyj E.I., Vorobets Z.D. $\mathrm{Na}^{+}, \mathrm{K}^{+}-\mathrm{ATP}$ ase and $\mathrm{Ca}^{2+}, \mathrm{Mg}^{2+}$ ATPase activity in spermatozoa of infertile men with different forms of pathospermia. Studia Biologica, 2017; 11(2): 5-12.

[DOI: https://doi.org/10.30970/sbi.1102.524; Google Scholar]

13. Naz M., Kamal M. Classification, causes, diagnosis and treatment of male infertility: a review. Oriental Pharmacy and Experimental Medicine, 2017; 17(2): 89-109.

[DOI: https://doi.org/10.1007/s13596-017-0269-7; Google Scholar]

14. Omu A. E. Sperm parameters: paradigmatic index of good health and longevity. Med. Princ. Pract., 2013; 22(1): 30-42.

[DOI: https://doi.org/10.1159/000354208; Google Scholar]

15. Publicover S., Harper C.V., Barratt C. $\left[\mathrm{Ca}^{2+}\right]_{i}$ signalling in sperm-making the most of what you've got. Nat Cell Biol, 2007; 9(3): 235-242.

[DOI: https://doi.org/10.1038/ncb0307-235; Google Scholar]

ISSN 1996-4536 (print) •ISSN 2311-0783 (on-line) • Біологічні Студії / Studia Biologica • 2020 • Том 14/№1 • C. 33-40 
16. Publicover S.J., Giojalas L.C., Teves M.E., de Oliveira G.S., García A.A., Barratt C.L., Harper C.V. $\mathrm{Ca}^{2+}$ signalling in the control of motility and guidance in mammalian sperm. Front. Biosci., 2008; 13: 5623-5637.

[DOI: https://doi.org/10.2741/3105; Google Scholar]

17. Vats Y.O., Klevets M.Y., Fedirko N.V. Kinetic characteristics of $\mathrm{Ca}^{2+}, \mathrm{Mg}^{2+}$-ATPase of cells of the submandibular salivary gland of rats. Ukr Biokhim J., 2004; 76(6): 44-54. (In Ukrainian)

18. Vignini A., Buldreghini E., Nanetti $L$. et al. Free thiols in human spermatozoa: are $\mathrm{Na}^{+} / \mathrm{K}^{+}-$ ATPase, $\mathrm{Ca}^{2+}$-ATPase activities involved in sperm motility through peroxynitrite formation? Reproductive BioMedicine Online, 2009; 18(1): 132-140.

[DOI: https://doi.org/10.1016/S1472-6483(10)60435-X; PMID: 19146780; Google Scholar]

19. World Health Organization. WHO laboratory manual for the examination and processing of human semen. 5th ed. Cambridge University Press, 2010; 271 p.

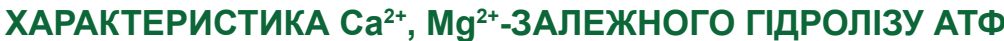 У СПЕРМАТОЗОЇДАХ ІНФЕРТИЛЬНИХ ЧОЛОВІКІВ
}

\author{
О. І. Мескало*, Р. В. Фафула, З. Д. Воробець \\ Львівський національний медичний університет імені Данила Галицького \\ вул. Пекарська, 69, Львів 79010, Україна \\ *Кореспондуючий автор: e-mail: gradst_meskalo_olga@meduniv.Iviv.ua
}

Порушення фертилізаційної здатності сперматозоїдів тісно асоційовані з дисфункцією йон-транспортувальних АТФаз, зокрема, $\mathrm{Ca}^{2+}, \mathrm{Mg}^{2+}$-АТФази. Знижена активність тапсигаргін-резистентної і тапсигаргін-чутливої $\mathrm{Ca}^{2+}, \mathrm{Mg}^{2+}$-АТФази призводить до порушення $\mathrm{Ca}^{2+}$-гомеостазу і $€$ характерною для аномальних сперматозоїдів (патозооспермія). 3 метою вивчення особливостей і механізму роботи $\mathrm{Ca}^{2+}$, $\mathrm{Mg}^{2+}$-АТФази визначали початкову швидкість реакції, максимальну (платову) кількість утворення продукту реакції та характеристичний час реакції. Для встановлення цих кінетичних параметрів $\mathrm{Ca}^{2+}, \mathrm{Mg}^{2+}$-залежного гідролізу АТФ, який каталізується $\mathrm{Ca}^{2+}, \mathrm{Mg}^{2+}$-АТФазою, досліджували динаміку накопичення продукту АТФ-гідролазної реакції. Отримані криві лінеаризовані у координатах $\{P / t ; P\}$. За оцінкою змін гідролазної активності $\mathrm{Ca}^{2+}, \mathrm{Mg}^{2+}$-АТФази досліджено кінетику первинно-активного транспортування йонів $\mathrm{Ca}^{2+}$ крізь плазматичну мембрану і мембрани внутрішньоклітинних $\mathrm{Ca}^{2+}$-депо у сапонін-пермеабілізованих сперматозоїдах інфертильних чоловіків із астено- й олігоастенозооспермією. З'ясовано, що у сперматозоїдах нормозооспермічних чоловіків транспортування йонів $\mathrm{Ca}^{2+}$ крізь плазматичну мембрану характеризується вищою ємністю, ніж крізь мембрани внутрішньоклітинних $\mathrm{Ca}^{2+}$-депо, однак відбувається з однаковою початковою швидкістю і характеристичним часом реакції. Встановлено, що у сперматозоїдах патоспермічних чоловіків транспортування йонів $\mathrm{Ca}^{2+}$ за участю обох компонент $\mathrm{Ca}^{2+}, \mathrm{Mg}^{2+}$-АТФази відбувається менш інтенсивно і характеризується нижчою ємністю, порівняно з сперматозоїдами чоловіків зі збереженою фертильністю. Вказані зміни кінетичних параметрів $\mathrm{Ca}^{2+}, \mathrm{Mg}^{2+}$-залежного гідролізу АТФ призводять до пригнічення активності тапсигаргін-резистентної і тапсигаргін-чутливої $\mathrm{Ca}^{2+}, \mathrm{Mg}^{2+}$-АТФази та зумовлюють зниження фрертилізаційного потенціалу сперматозоїдів.

Ключові слова: $\mathrm{Ca}^{2+}, \mathrm{Mg}^{2+}$-АТФаза, гідроліз АТФ, сперматозоїди, чоловіче непліддя, патоспермія

Received / Одержано 11 February 2020
Accepted / Прийнято 11 March 2020
Published / Опубліковано 5 May 2020

ISSN 1996-4536 (print) • ISSN 2311-0783 (on-line) • Біологічні Студії / Studia Biologica • 2020 • Том 14/№1 • С. 33-40 